\title{
Presepsi Siswa Terhadap Pelayanan Perpustakaan di MAN 1 Kota Kediri
}

\author{
Adam Dwi Nur Fikry M \\ 200607110028 \\ Jurusan Perpustakaan dan Ilmu Informasi Fakultas Sains dan Teknologi \\ UIN Maulana Malik Ibrahim Malang \\ Jalan Gajayana No. 50 Malang 65144
}

\begin{abstract}
Abstrak
Penelitian ini bertujuan untuk mengetahui pengaruh kualitas pelayanan dan fasilitas perpustakaan terhadap kepuasan para siswa di MAN 1 kota Kediri. Pada penelitian ini penulis menggunakan metode deskriptif kuantitatif, terdapat responden yang ditujukan kepada para siswa MAN 1 kota Kediri untuk mengetahui langsung tanggapan dari mereka. Perpustakaan sekolah merupakan tempat yang disediakan oleh pihak sekolah, dikelola,dan diberdayakan di lingkungan sekolah. Keberadaan perpustakaan di lingkungan sekolah memiliki peran yang penting untuk menunjang para siswa untuk mampu berkembang dan meningkatkan kulitas literasi di lingkungan sekolah. Manajemen perpustakaan sekolah yang ada pada dasarnya adalah proses mengoptimalkan kontribusi manusia, material, anggaran untuk mencapai tujuan perpustakaan di bawah institusi sekolahan, di dalam manajemen tersebut terdapat aspek pelayanan dan fasilitas yang diberikan kepada para siswa. Pelayananan yang diberikan memilii dampak besar terhadap tingkat kunjungan para siswa untuk datang ke perpustakaan sekolah.
\end{abstract}

Kata kunci: Kualitas Pelayanan, Fasilitas Perpustakaan, dan Tingkat Kepuasan Siswa

\section{Pendahuluan}

Kebutuhan masyarakat terhadap informasi dan media edukasi merupakan hal penting dan menjadi tantangan bagi penyedia jasa informasi dan edukasi. Lembaga pendidikan seperti Madrasah Aliyah (MA) yang bergerak di bidang edukasi dan informasi juga tidak luput dari perkembangan teknologi informasi yang cepat dan di tuntut untuk meningkatkan pelayanan di bidang pendidikan. Salah satu sumber informasi dan media edukasi ialah keberadaaan perpustakaan sekolah yang dimana disediakan oleh pihak sekolah guna menyimpan buku maupun bahan koleksi lainya. Penataan koleksi buku yang rapi dan pelayanan yang profesional dari petugas serta fasilitas yang disediakan oleh pengelola perpustakaan sangat diharapkan oleh para siswa. Selain itu ruang baca yang menarik dan fungsional akan memberikan suasana yang hidup didalam perpustakaan sekolah. Sebagai salah satu peran pendidikan, perpustakaan sekolah mempunyai fungsi sebagai penunjang kegiatan belajar 
siswa, membantu siswa dan guru dalam mencapai tujuan pendidikan di sekolah pada umumunya. Kualitas pelayanan yang diterima oleh pengguna perpustakaan akan mempengaruhi perilaku dan loyalitas di waktu yang akan datang.

Dalam sebuah jurnal yang di tulis oleh Dewi pada tahun 2015 menyatakan bahwa :

"Pelayanan merupakan suatu bentuk kegiatan sosial untuk membantu orang lain dan mempunyai tujuan membangun kerja sama antar pihak dalam jangka panjang dengan prinsip saling menguntungkan antar pihak terkait (Dewi, 2015)".

Dilihat dari aspek koleksinya, banyak perpustakaan sekolah yang hanya mempunyai buku paket mata pelajaran,yang merupakan buku ajar maupun buku teks yang digunakan dalam keberlangsung kegiatan belajar mengajar. Koleksi lain yang berorientasi pada aspek rekreatif cultural sangat kurang.

Dalam sebuah tulisannya yang berjudul 'Kualitas Pelayanan Di Perpustakaan Sma Muhammadiyah 2 Surabaya' Purwanto juga menyatakan bahwa :

padahal koleksi penunjang, misal buku fiksi sangat penting khususnya untuk meningkatkan daya berimajinasi dan menumbukan motivasi membaca (Purwanto, 2008).

Ketika kegiatan belajar mengajar berlangsung para siswa tidak diharuskan untuk menerima informasi berupa pelajaran yang disampaikan guru dan buku paket yang diberikan oleh pihak sekolah. Para siswa diberi keleluasaan dan kebebasan untuk mendapatkan sebuah ilmu dan informasi, salah satunya dari perpustakaan sekolah. Oleh karena itu perpustakaan sekolah wajib memberikan dan menyediakan koleksi yang mampu menunjang siswa dalam mengekspresikan kebebasanya melalui membaca dan mencari sebuah informasi dari berbagai buku di perpustakaan sekolah. Perpustakaan dituntut untuk mengembangkan koleksi tercetak dan elektronik serta menyediakan sarana dan prasarana untuk memanfaatkan informasi yang tersedia dan tentu saja pengembangan pustakawan perlu ditingkatkan untuk mengoptimalkan pelayanan perpustakaan. Maka dari itu pelayanan yang diberikan oleh pustakawan haruslah yang sesuai dengan lingkungan mereka, dengan ramah, mudah dalam prosesnya dan mudah diterima oleh siswa dengan memberikan ruang yang terbuka dan mudah diterima oleh para siswa.

Berdasarkan uraian diatas perpustakaan sekolah di MAN 1 kota Kediri belum sepenuhnya bejalan dengan maksimal. Hasil pra survey yang penulis lakukan di perpustakaan MAN 1 kota Kediri, kondisi yang ada diperpustakaan tersebut belum maksimal dalam memberikan kualitas pelayanan yang baik kepada siswa atau dengan kata lain belum di kelola 
dengan baik berdasarkan aturan - aturan dalam mengelolah perpustakaan. Sebab penulis melihat perencanaan dan pelaksanaan terhadap pembinaan koleksi belum maksimal, kemudian terdapat juga koleksi yang kondisinya perlu diperhatikan, hal ini mengakibatkan kualitas informasi yang diberikan kepada para siswa atau guru belum efisien di perpustakaan MAN 1 kota Kediri. Dalam proses pengklasifikasian koleksi ini belum terlaksana berdasarkan peraturan perpustakaan pada umumya, guna membuat sistem temu kembali informasi di MAN 1 kota Kediri hal ini mengakibatkan para siswa kesulitan dalam menelusur suatu informasi dan kebutuhannya akan informasi belum bisa terpenuhi dan terwujud dengan baik.

\section{Tinjauan Pustaka}

\section{a. Pengertian Persepsi}

Menurut kamus Besar Bahasa Indonesia (KBBI) :

"Persepsi menurut Kamus Besar Bahasa Indonesia (KBBI) adalah tanggapan (penerimaan) langsung dari sesuatu atau proses seseorang mengetahui beberapa hal melalui panca inderanya (Pusat Bahasa Departemen Pendidikan Nasional, 2008)."

Dalam sebuah jurnal yang di tulis oleh Hendra juga menyatakan bahwa :

"Persepsi mencakup penerimaan stimuslus (inputs), mengorganisasikan stimulus dan penerjemahan atau penafsiran stimulus yang telah diorganisasi dengan cara yang dapat mempengaruhi prilaku dan membentuk sikap, sehingga orang dapat cenderung menafsirkan prilaku orang lain sesuai dengan keadaannya sendiri (Hendra, 2017)."

Dalam penellitian yang dilakukan oleh Purwanto dengan judul "Kualitas Pelayanan Di Perpustakaan Sma Muhammadiyah 2 Surabaya Menggunakan Pendekatan Model SERVQUAL) (2008)" menyatakan bahwa ,

“Alasan peneliti melakukan penelitianini untuk mengetahui kualitas layanan perpustakaan sekolah dan akan dilakukan di Perpustakaan SMA Muhammadiyah 2 Surabaya dengan menggunakan SERVQUAL. Metode SERVQUAL adalah sebuah survey dalam konteks penelitian untuk menilai kualitas pelayanan perpustakaan, metode SERVQUAL dapat memberikan kesempatan pada siswa untuk memberitahukan kondisi layanan di perpustakaan sekolah misalkan apakah perlu dilakukan perbaikan, sehingga 
perpustakaan dapat menanggapi sesuai dengan keinginan siswa (Purwanto, 2008)".

Pada tulisan ini penulis menggunakan objek beberapa siswa di MAN 1 kota Kedirisebagai penunjang penelitian ini dengan memberikan kuisioner kepada beberapa siswa yang ditujukan sebagai sempel, setelah data terkumpul penulis menggunakan metode deskriptif kuantitatif dalam mengolah data yang terkumpul.

Metode deskriptif kuantitatif merupakan suatu penelitian yang mempunyai tujuan untuk mendeskripsikan suatu peristuwa yang terjadi secara factual, sistemasis serta akurat, penjelasan lebih lanjut mengenai penjabara metode akan dibahas pada bab metedologi penelitian.

Penulis memberi batasan masalah pada masalah yang akan di bahas mengingat keterbatasan waktu dalam proses penyusunan, agar pembahasan tidak meluas dan menyimpang bahasan lain maka penulis memberikan batasan masalah yaitu, Presepsi Siswa Terhadap Pelayanan di MAN 1 kota Kediri.

\section{b. Pengertian Pelayanan}

Pelayanan pada dasarnya dapat didefinisikan sebagai aktifitas seseorang, sekelompok atau organisasi baik langsung maupun tidak langsung untuk memenuhi kebutuhan. Moenir Mengatakan bahwa pelayanan adalah proses pemenuhan kebutuhan melalui aktivitas orang lain secara langsung.

Pengertian pelayanan Menurut Kamus Besar Bahasa Indonesia (KBBI) (2005:826), menyatakan bahwa :

"Perihal atau cara untuk melayani / kemudahan yang diberikan sehubungan dengan jual beli barang atau jasa."

Dalam jurnal lain yang ditulis oleh Hendra H dengan judul 'Persepsi Siswa Terhadapap Pelayanan Jasa Pendidikan pada Lembaga Pendidikan El Rahma Palembang' menyatakan bahwa :

“pelayanan adalah aktivitas yang dilakukan seseorang atau sekelompok orang dengan landasan faktor material melalui sistem, prosedur dan metode tertentu dalam rangka memenuhi kebutuhan orang lain sesuai dengan haknya. Hal ini menjelaskan bahwa pelayanan adalah suatu bentuk sistem, prosedur atau metode tertentu yang diberikan kepada oarang lain dalam hal ini pelanggan agar kebutuhan pelanggan tersebut dapat terpenuhi sesuai dengan harapan mereka" 


\section{Metode Penelitian}

Metode Penelitian

Dalam sebuah tulisan Mulyadi mengartikan penelitian dengan menyatakan bahwa :

"Penelitian adalah sebuah proses kegiatan yang bertujuan untuk mengetahui sesuatu secara teliti, kritis dalam mencari fakta-fakta dengan menggunakan langkah-langkah tertentu. Keinginan untuk mengetahui sesuatu tersebut secara teliti, muncul karena adanya suatu masalah yang membutuhkan jawaban yang benar (Mulyadi, 2011)”.

Metode 'deskriptif kuantitatif' merupakan suatu penelitian yang mempunyai tujuan untuk mendeskripsikan suatu peristuwa yang terjadi secara factual, sistemasis serta akurat. Peristiwa yang terjadi dapat berupa bentuk, aktivitas, hubunganpersamaan mau puun perbedaan antar peristiwa. Masalah kuantitatif lebih umum memiliki wilayah yang luas, tingkat variasi yang kompleks namun berlokasi dipermukaan. Akan tetapi masalah-masalah kualitatif berwilayah pada ruang yang sempit dengan tingkat variasi yang rendah namun memiliki kedalaman bahasan yang tak terbatas (Mulyadi, 2011).

Pada instrument penulisan ini penulis mengimplementasikanya dengan menyebarkan atau memberikan angket kuisioner kepada beberapa siswa yang dijadikan objek sampel. Kuisioner berisikan beberapa pertanyaan tentang presepsi terhadap pelayanan di perpustakaan MAN 1 kota Kediri kepada pengguna yang merasakan secara langsung.

\section{Pembahasan dan Hasil}

\section{Pembahasan}

\section{Perpustakaan sekolah}

Dalam sebuah jurnal yang ditulis oleh Rokhan Reza (2017) dengan judul 'manajemen perpustakaan sekolah' mengatakan bahwa :

"Dalam pengertian lain disebutkan bahwa manajemen perpustakaan adalah proses pengelolaan perpustakaan dengan didasarkan pada prinsip-prinsip dan teori-teori manajemen. Pada hakekataya manajemen adalah suatu kegiatan untuk mencapattujuan,melalui kerja orang-orang lain (Reza, 2017).”

Perpustakaan sekolah yang dikepalai langsung oleh kepala sekolah sebisa mungkin memiliki program kerja sediri untuk perpustakaan dan para petugas/karyawan yang ada di perpustakaan perlu diberdayakan agar mereka para staf karyawan dapat mengembangkan 
kreativitas dan produktivitas kerja bagi kepentingan kualitas layanan pemakai secara optimal. Perpustakaan sekolah bregerak untuk membantu para siswa dan guru dalam mencari sumber informasi yang jelas, terstruktur dan terjangkau karena berada dilingkungan sekolah, juga menyediakan wadah organisasi bagi mereka para siswa yang memiliki ketertarikan terhadap buku-buku dan perpustakaan.

\section{Fasilitas}

Dalam sebuah tulisan yang di tulis oleh Dewi dengan judul 'Pengaruh Kualitas Pelayanan dan Fasilitas Perpustakaan terhadap Prestasi Belajar Mahasiswa Universitas Samudra' menyatakan bahwa :

"fasilitas adalah sumber daya fisik yang harus ada sebelum suatu jasa ditawarkan kepada sebagian atau semua pelanggan untuk pelanggan. Dilanjutkannya bahwa fasilitas merupakan sesuatu yang sangat penting dalam usaha jasa, oleh karena itu fasilitas yang ada diberikan. Perusahaan dapat pula yaitu kondisi fasilitas, kelengkapan desaign memberikan kemudahan bagi para interior dan eksterior serta kebersihan fasilitas yang harus dipertimbangkan terutama yang menyangkut kebutuhan maupun yang dirasakan pelanggan secara langsung (Dewi, 2015)."

Pada zaman perkembangan teknologi digital (IPTEK) saat ini sangat pesat dan cepat yang membuat seluruh faktor yang menjadi medianya berubah dan menyebrang kearah digital termasuk perpustakaan yang berperan aktif sebagai penyedia informasi yang actual, factual dan uptodate. Sekarang perpustakaan berkembang kearah digital. Hendaknya perpustakaan sekolah selalu diusahakan untuk mengembangkan fasilitas dan sumber daya manusia (SDM) dalam pengelolaan perpustakaan secara terstruktur dan optimal seingga, perpustakaan sekolah tetap mendapatkan tempat bagi para siswa dan guru.

Dalam jurnal yang ditulis Mutia 'berjudul sarana dan prasarana ruang perpustakaan sebagai aspek kekuatan dalam mengembangkan perpustakaan' menyatakan :

\footnotetext{
"Peralatan perpustakaan merupakan alat yang dipergunakan staf (pustakawan) untuk menyelesaikan tugas utamanya sehingga kegiatan didalam perpustakaan berjalan secara optimal sesuai fungsi yang ingin diwujudkannya (Mutia, 2011).”
} 


\section{Hasil Survey}

Setelah melakukan survey dengan membagikan kuisioner, berdasarkan pada pengumpulan dan pengolahan data yang telah dilakukan, maka diperoleh karakteristik responden, hasil survey keluhan, identifikasi permasalahan serta pengelompokan masalah. Penjelasan akan hal tersebut dapat dilihat dari beberapa point yang akan diuraikan

A. Data Karakteristik Responden

Data karakteristik responden yang dikumpulkan antara lain kecepatan pelayanan, kompetensi pustakawan, fasilitas perpustakaan, keramahan dan kesopanan serta kepuasan para siswa setelah berkunjung ke perpustakaan. Berikut hasil kuisoner yang diberikan kepada siswa MAN 1 kota Kediri.

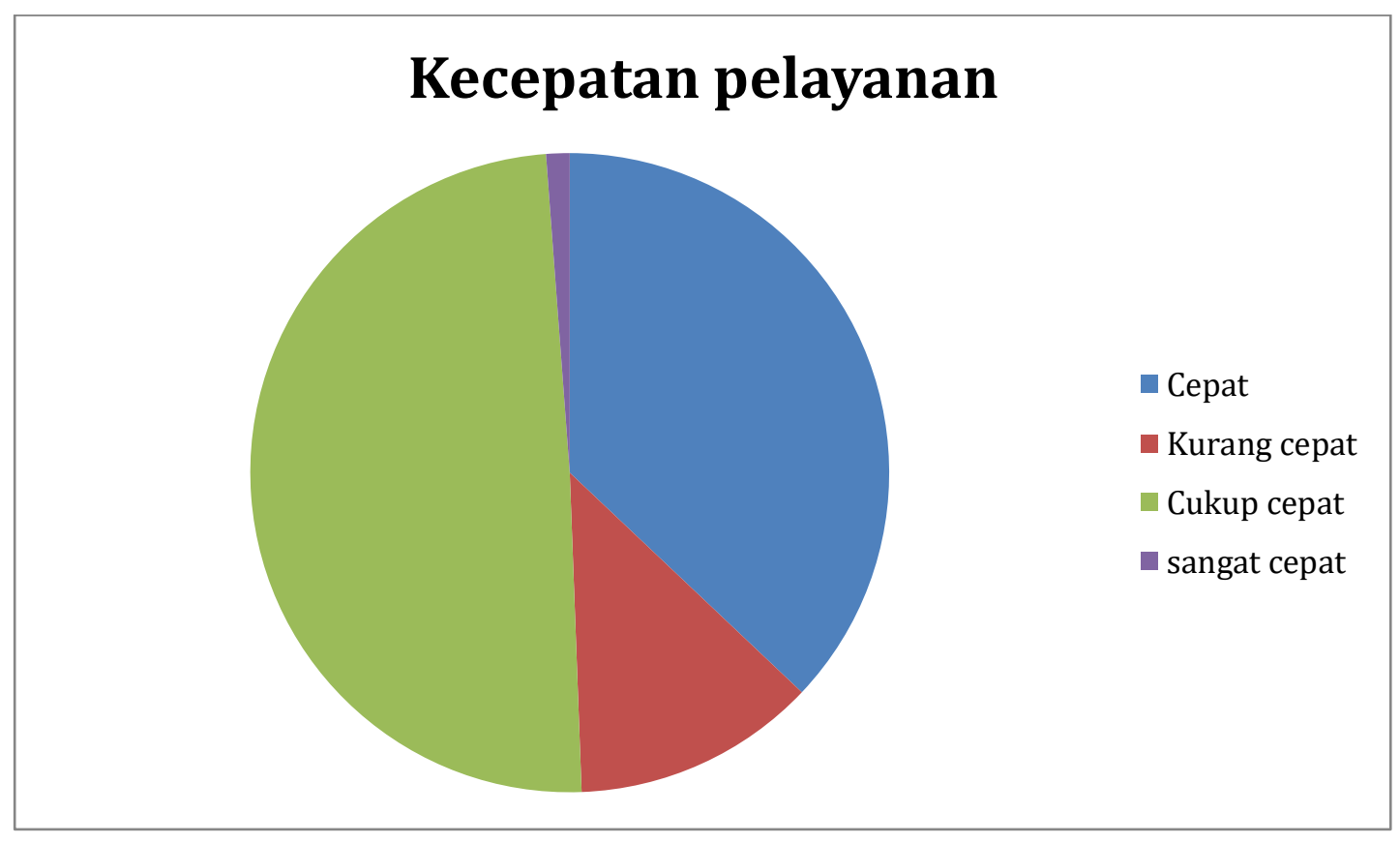

Dari tabel diatas menunjukan bahwa pelayanan yang di berikan kepada para siswa yang datang ke perpustakaan mendapatkan presentase $37.5 \%$ responden memberikan jawaban kurang cepat. Kemudian mendapatkan presentase $12.5 \%$ responden memberikan jawaban lambat dalam memberikan pelayanan, dari presentase lambat tersebut menunjukan bahwa beberapa dari responden mendapatkan pengalaman yang kurang baik dari tingkat pelayanan yang di berikan oleh pustakawan. Dan presentase 50\% diberikan responden untuk pelayanan yang cukup cepat. Presentase diatas belum sepenuhnya cukup dijadikan indikator namun juga sebagai bahan evaluasi untuk kualitas kecepatan pelayanan di perpustakaan MAN 1 kota Kediri kedepanya. 


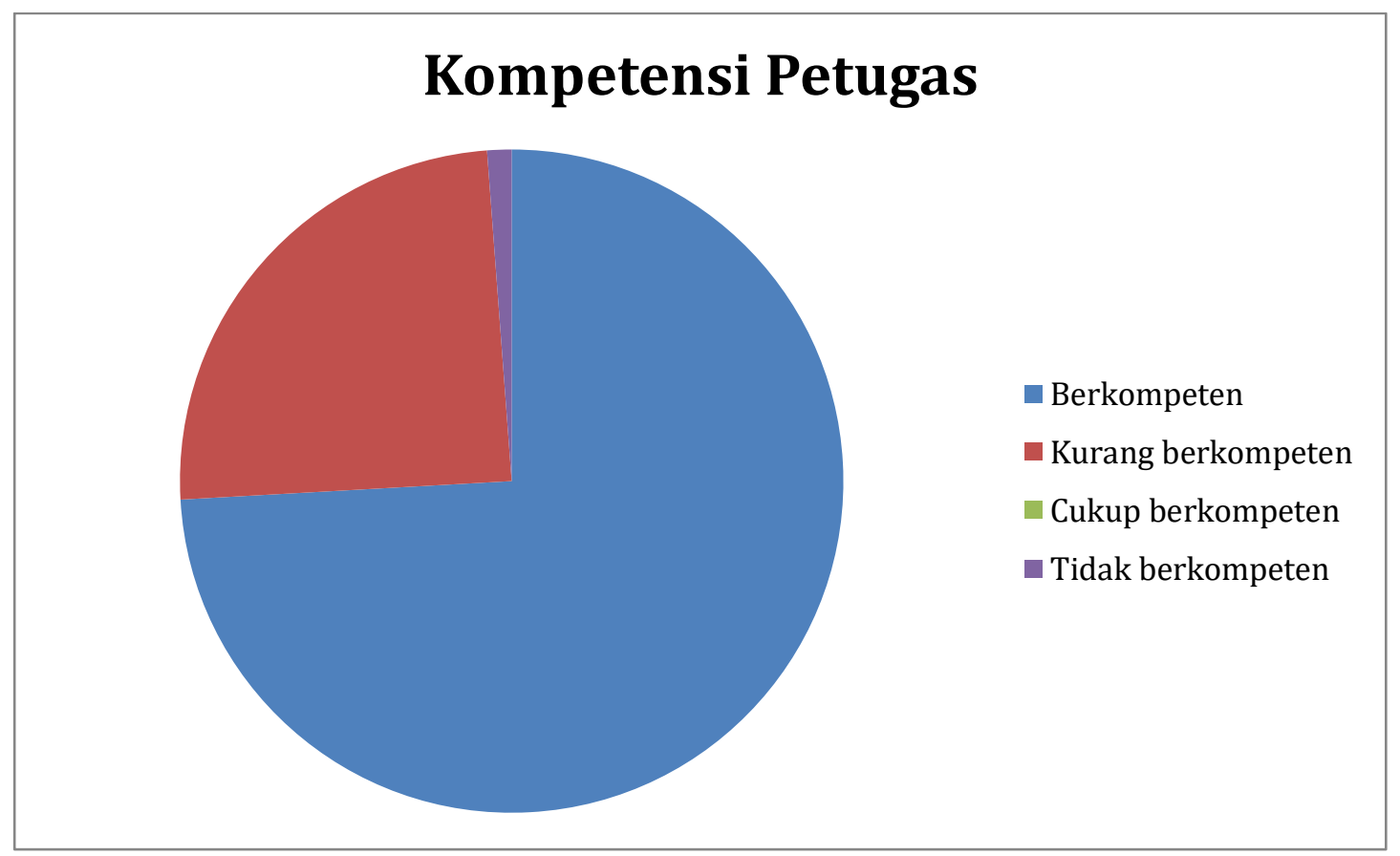

Dapat dilihat dari tabel diatas bahwa dalam segi kompetensi petugas/pustakawan tercatat $75 \%$ yang diberikan responden untuk kompetensi pustakawan dan sisanya memberikan $25 \%$ merasa bahwa pustakwan masih kurang berkompeten. Dari tabel diatas dapat dijadikan evaluasi terhadap kompetensi tiap pustakawan sehingga terus belajar untuk berkembang kedepanya, sehingga para siswa merasa terbantu dengan adanya pustakawan yang berkompeten di perpustakaan sekolah mereka.

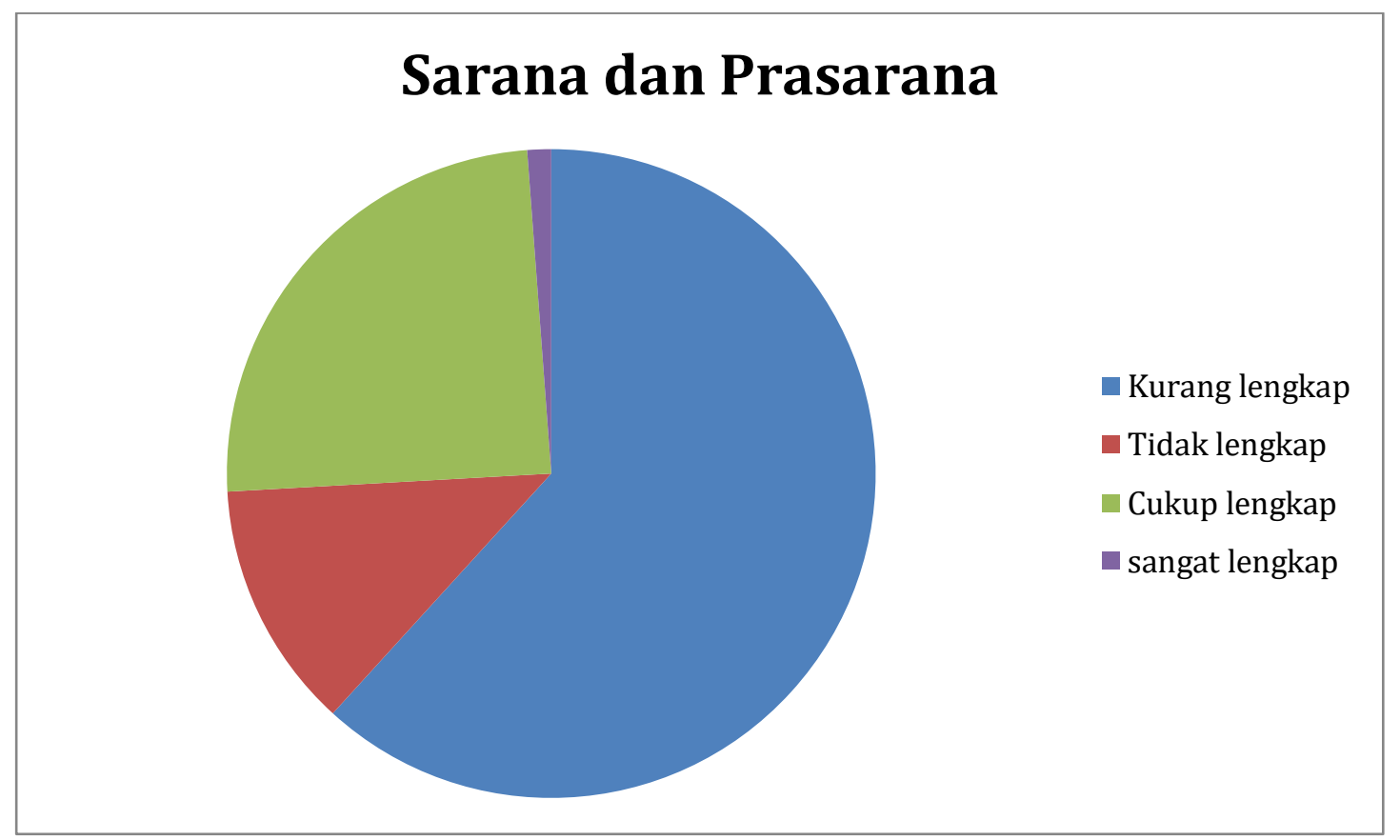

Sebagai perpustakaan sekolah yang memiliki kelompok penggunjung remaja, daya tarik merupakan hal yang patutu untuk diperhatikan. Dalam tulisannya Mutia menjabarkan beberapa barang yang harusnya tersedia diperpustakaan meliputi : 
"Peralatan perpustakaan termasuk didalamnya barang- barang yang diperlukan secara langsung untuk mengerjakan tugas/kegiatan di perpustakaan seperti buku pedoman perpustakaan, buku klasifikasi, kartu katalog, buku induk, kantong buku, stempel inventaris, mesin ketik (komputer), alat tulis kantor, selotip, lem dan lain sebagainya (Mutia, 2011)”.

Responden memberikan presentase $62.5 \%$ dengan klasifikasi kurang lengkap, $12.5 \%$ tidak lengkap dan $25 \%$ cukup lengkap. Hasil presentase tersebut memberikan jawaban dan gambaran secara langsung bahwa fasilitas yang terseedia diperpustakaan MAN 1 perlu peningkatan yang cukup besar. Sehingga perlunya peningkatan dalam segi sarana dan prasarana untuk menunjang para siswa tekita berkunjung ke perpustakaan.

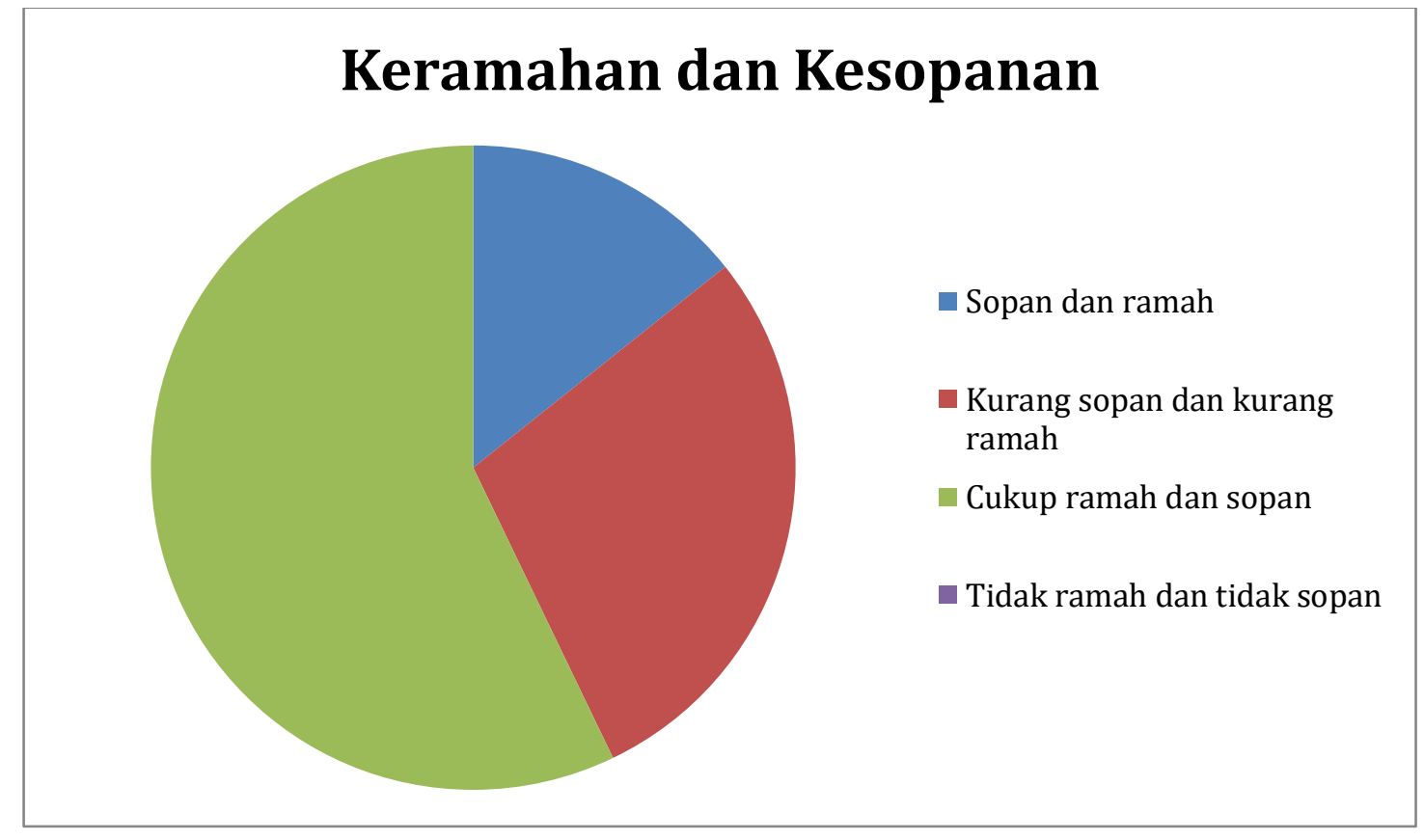

Dapat dilihat pada tabel di atas responden memiliki pengalaman yang beragam dalam respon prilaku keramahan dan kesopanan petugas perpustakaan. Hasil presentase menunjukan $12 \%$ petugas memiliki sikap sopan dan ramah, $25 \%$ mendapatkan pengalaman yang kurang baik dalam pelayanan keramahan petugas dan 50\% mendapatkan perlakuan yang cukup rama dan sopan. Hal tersebut bukan tolak ukur yang akurat namun dapat dijadikan bahan kajian untuk memberikan pelayanan penuuh dan baik terhadap semua pengunjung/siswa. dalam tulisanya Guntara mengatakan bahwa :

"Kesan pemustaka terhadap indikatorvemphaty (empati) dapat dilihat dari aspek mendahulukan kepentingan pelanggan, petugas melayani dengan sikap ramah, petugas melayani dengan sikap sopan santun dan tidak diskriminatif (membeda-bedakan) (Guntara, Bintang S. Suryani, 2017).” 


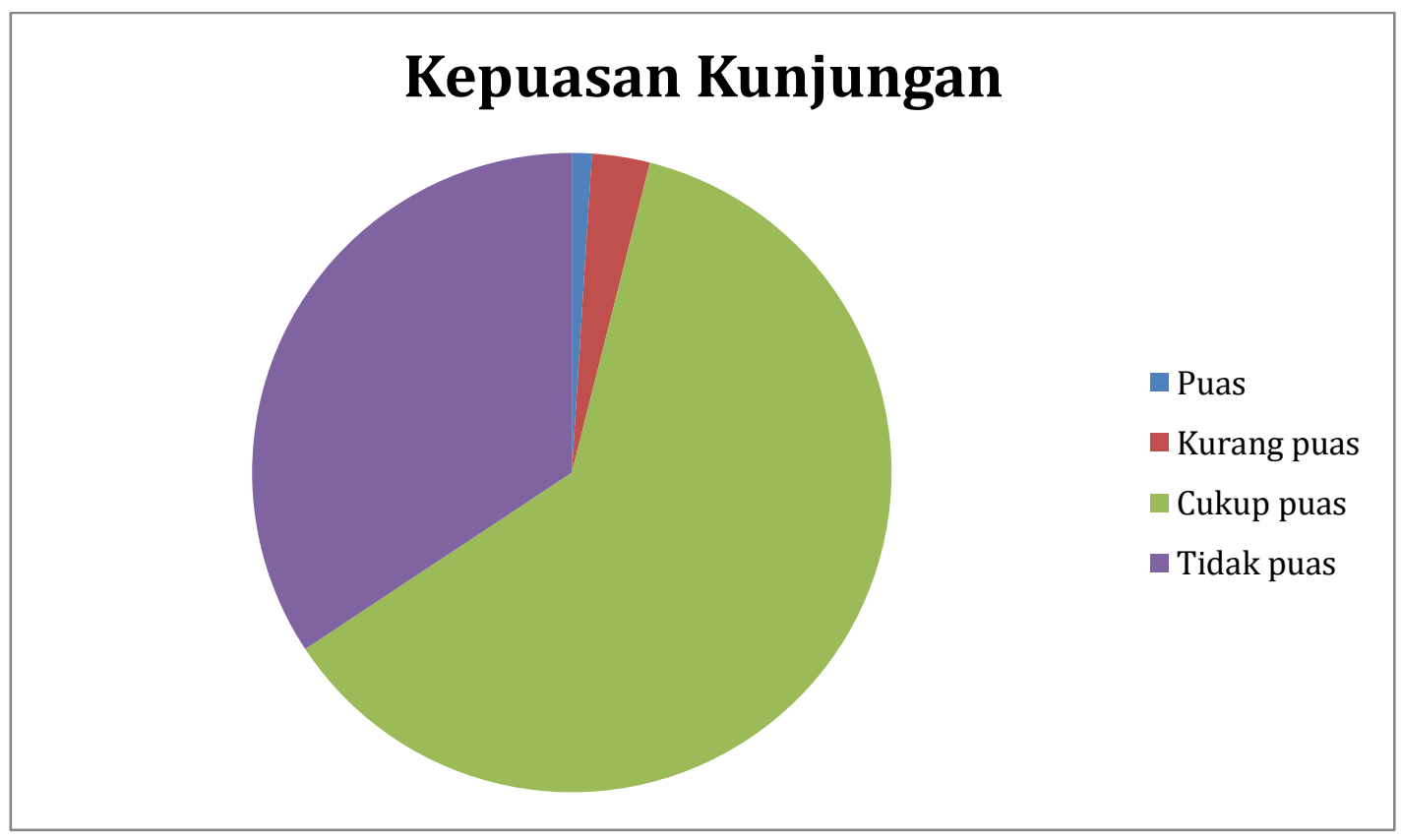

Para responden sepertinya cukup puas dengan pelayanan yang di berikan ole petugas dengan memberikan presentase $62.5 \%$ dan sisanya meberikan $37.5 \%$ merasa tidak puas. Tingkat kepuasan kunjungan para siswa tidak dapat dilihat atau dinilai dari satu barometer/aspek tertentu, ada begitu banyak aspek yang menjadi faktor kepuasan pengunjung. Semua itu dijadikan evalusai untuk perpustakaan MAN 1 kota Kediri yang lebih terimplementasi dengan terstruktur, inovatif dan solutif.

\section{Kesimpulan}

Disadari bahwa penataan ruang perpustakaan yang memenuhi syarat estetika yang baik dan nyaman harus didukung oleh sarana dan prasarana (peralatan dan perlengkapan) yang ergonomis, sehingga dapat menjadi aspek kekuatan guna pengembangan perpustakaan secara terus menerus. peran serta perpustakaan sekolah. Dengan kemajuan teknologi pustakawan harus meningkatkan kualitas serta kepekaannya terhadap kemajuan-kemajuan yang ada hubungannya dengan perkembangan serta peningkatan pelayanan. Anggaran merupakan faktor yang sangat penting dalam menentukan keberhasilan suatu perpustakaan. Di zaman serba digital ini perlu peningkatan SDM beserta penunjang lainya untuk terus berjalanya perpustakaan sekolah, dengan tujuan perpustakaan tidak akan ditinggal oleh para siswa dan guru meskipun informasi diinternet mengalir deras tiap harinya. Pihak sekolah dan pengelola perpustakaan sekolah harus memiliki komunikasi yang bagus untuk semua itu agar tujuan perpustakaan sekolah sebagai penunjang untuk mewujudkan pendidikann yang berkompeten dan tercapainya tujuan, visi dan misi sebuah sekolah. 


\section{Saran}

Berdasarkan hasil survey dan tulisan di atas mengenai manajemen perpustakaan MAN 1 kota Kediri, penullis memberikan saran kepada pihak terkait, antara lain :

1. Kurang rapinya penataan buku yang masih tercecer tidak berada dirak buku, perlunya pengelolaan buku maupun koleksi yang ada dengan seefektif mungkin.

2. Pelayanan yang diberikan masih kurang memberikan kesan kepuasan tersendiri bagi beberapa siswa/pengunjung, terlihat dari jawaban yang diberikan oleh beberapa siswa/pengunjung melalui kuisioner yang diberikan.

3. Sarana dan prasarana yang masih perlu di lengkapi karena masih banyaknya fasilitas yang belum ada dan yang ada pun perlu pembaharuan.

4. Koleksi yang disediakan masih perku peningkatan agar para siswa memiliki ketertarikan untuk berkujung ke perpustakaan dan perpustakaan mempunyai daya tarik bagi para siswa dan guru.

5. Kecepatan pelayanan yang harus terus ditingkatkan guna memberikan peayanan yang maksimal kepada semua siswa dan guru di MAN 1 kota Kediri.

Terlepas dari semua itu penulis menyadari sepenuhnya bahwasanya tulisan ini jauh dari kata sempurna masih terlalu banyak hal yang perlu dikoreksi ulang dan ditingkatkan. Harapan penulis tulisan ini mampu menjadi bahan refleksi dan koreksi kepada kedua belah pihak. Berdasarkan hasil penelitian yang telah dilakukan, hasil kuesioner menunjukkan bahwa hasil penelitian nantinya dapat dijadikan rujukan dalam penelitian selanjutnya. 


\section{Daftar Pustaka}

Dewi, M. (2015). Pengaruh Kualitas Pelayanan dan Fasilitas Perpustakaan terhadap Prestasi Belajar Mahasiswa Universitas Samudra. 4(1), 203-213.

Guntara, Bintang S. Suryani, N. (2017). PENGARUH PENGOLAHAN KOLEKSI, KOMPETENSI PENGELOLA, DAN FASILITAS PERPUSTAKAAN TERHADAP KUALITAS PELAYANAN PERPUSTAKAAN. 6(3), 973-986.

Hendra, H. (2017). Persepsi Siswa Terhadapap Pelayanan Jasa Pendidikan pada Lembaga Pendidikan El Rahma Palembang. Jurnal Ekonomi Dan Informasi Akuntansi (Jenius, VOL. 1 NO.(81588), 221-237.

Mulyadi, M. (2011). PENELITIAN KUANTITATIF DAN KUALITATIF SERTA PEMIKIRAN DASAR MENGGABUNGKANNYA Mohammad Mulyadi. 15(1), 127-138.

Mutia, F. (2011). Sarana dan prasarana ruang perpustakaan sebagai aspek kekuatan dalam mengembangkan perpustakaan. 1-8.

Purwanto, D. O. (2008). Kualitas Pelayanan Di Perpustakaan Sma Muhammadiyah 2 Surabaya Menggunakan Pendekatan Model SERVQUAL). 1-17.

Pusat Bahasa Departemen Pendidikan Nasional. (2008). Kamus Bahasa Indonesia. In Statewide Agricultural Land Use Baseline 2015 (Vol. 1). https://doi.org/10.1017/CBO9781107415324.004

Reza, M. R. (2017). Manajemen Perpustakaan Sekolah. 11(01), 1-14. 


\section{Lampiran}
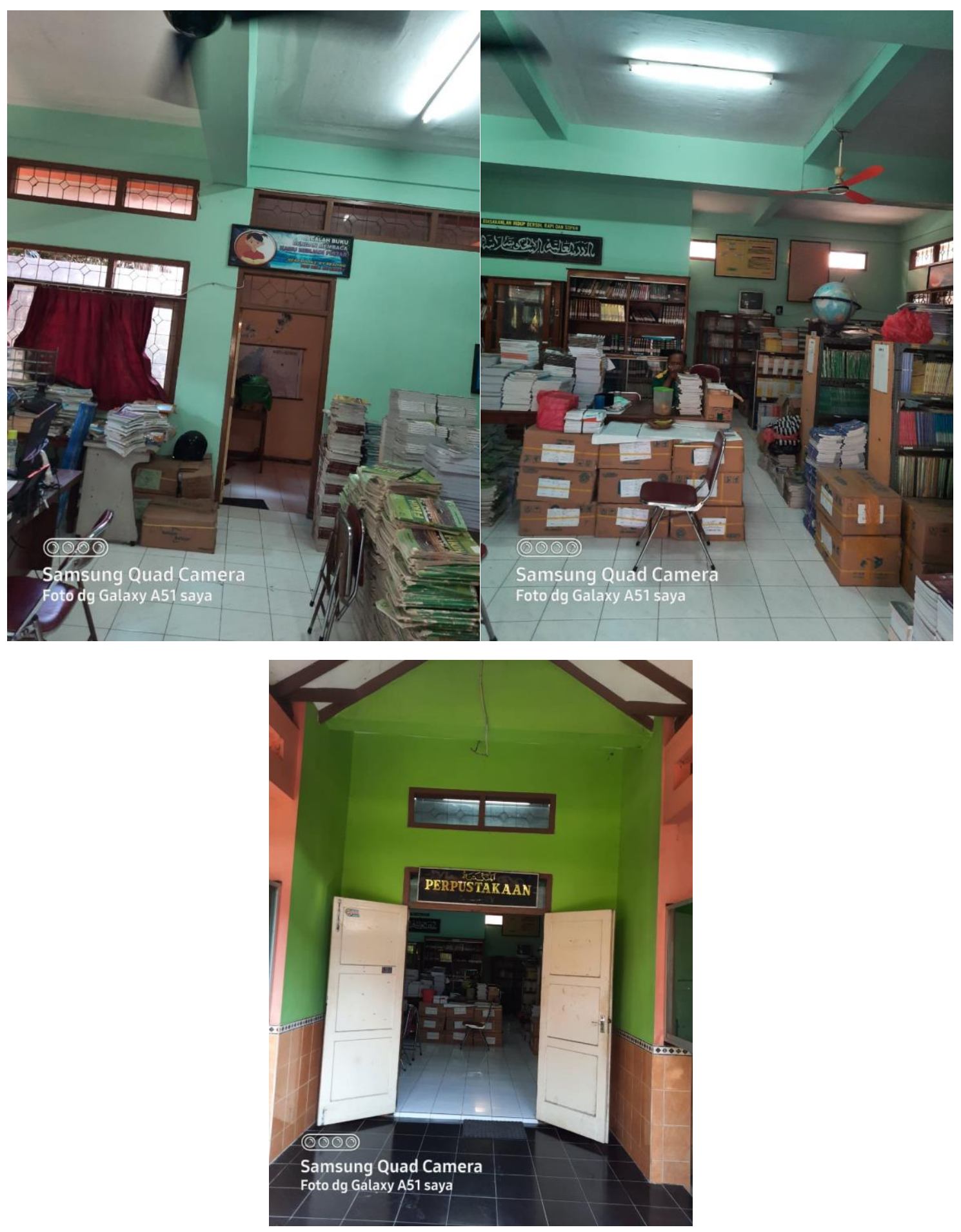

Gambar 1. Perpustakaan MAN 1 kota Kediri 